\title{
Is There a Role for the IGF System and Epidermal Growth Factor (EGF) in the Pathogenesis of Adrenocortical Adenomas? A Preliminary Case-Control Study
}

\author{
Ivica LAZÚROVÁ ${ }^{1}$, Ivana JOCHMANOVÁ ${ }^{1}$, Štefan SOTAK ${ }^{1}$, Ivana ŠPAKOVÁ ${ }^{2}$, Mária \\ MAREKOVÁ ${ }^{2}$ \\ ${ }^{1}$ Department of Internal Medicine 1, Faculty of Medicine, P.J. Šafárik University, Košice, Slovakia, \\ ${ }^{2}$ Department of Medical and Clinical Biochemistry, Faculty of Medicine, P.J. Šafárik University, \\ Košice, Slovakia
}

Received July 30, 2020

Accepted September 29, 2020

Epub Ahead of Print November 19, 2020

\section{Summary}

Adrenal incidentalomas (AI) are very common and mostly they are non-functioning adenomas (NFA). NFAs are often associated with insulin resistance and metabolic syndrome. Several biomarkers, including certain growth factors, may participate in the pathogenesis of metabolic changes in patients with adrenal adenomas. Patients with NFA and age-matched control subjects were enrolled in the study. Data on age, gender, presence of metabolic syndrome or its components were obtained for each subject. Blood samples were obtained and glycemia, insulinemia, lipid profile, and selected growth factor levels were measured. Forty-three patients with NFA and 40 controls were included in the study. Differences were not found in the metabolic syndrome and its components prevalence or in the biochemical profile between patients and the control group. Significant differences were noticed in the levels of IGF1, IGF2, and IGFBP3 ( $p=0.016$, $p=0.005, p=0.004$, respectively), but there were no differences in VEGF or EGF concentrations. In NFA patients, an association between glycemia and EGF levels was present $(p=0.026)$. No significant correlations between tumor size and insulin or growth factor concentrations were present in AI patients. Significantly higher serum IGF1, IGF2, and IGFBP3 concentrations in NFA patients may support the role of the IGF axis in the pathogenesis of adrenocortical lesions. No correlation between IGFs or IGFBP3 and parameters of glucose or lipid metabolism was found. Present results may support the role of the growth hormone axis rather than hyperinsulinemia and insulin resistance in the pathogenesis of adrenocortical adenomas.

\section{Key words}

Adrenal incidentaloma - Adrenocortical adenoma - Growth factors • Metabolic syndrome $\bullet$ Insulin resistance

\section{Corresponding author}

Ivica Lazúrová, Department of Internal medicine 1, Medical Faculty of P.J. Šafarik University Košice, Trieda SNP 1, 04011 Košice, Slovakia. E-mail: ivica.lazurova@upjs.sk

\section{Introduction}

Adrenal incidentalomas (AI) are among the most common tumors in humans with an estimated prevalence of $1-8 \%$. The vast majority of these tumors are benign adrenocortical adenomas (ACA, Fassnacht et al. 2016). Some of them produce hormones but, in most cases, they are non-functioning adenomas (NFA, Khan 2019). Although patients with NFA do not show any overt physical signs of excessive hormonal production, they are often insulin resistant and have metabolic syndrome (Muscogiuri et al. 2017). Currently, it is not completely clear if ACA development results from primary insulin resistance and compensatory hyperinsulinemia, or insulin resistance develops secondly due to the slight cortisol hypersecretion by AI (Papanastasiou et al. 2017, Di Dalmazi 2017). Recent studies showed that the degree of insulin resistance directly correlates with the AI size (Delibasi et al. 2015). This allows hypothesizing that hyperinsulinemia could have mitogenic and mutagenic

PHYSIOLOGICAL RESEARCH • ISSN 1802-9973 (online) 
effects on the adrenal cortex through the activation of insulin (insulin resistance) and insulin-like growth factor (IGF) system. Several biomarkers have been identified to be involved in the pathogenesis of obesity and insulin resistance in humans and also in patients with ACA. Besides various proinflammatory cytokines and adipocytokines, IGF1and IGF2 are the most studied insulin-like peptides regulating a large number of important physiological processes (Livingstone and Borai 2014, Anderlová et al. 2019). IGF1 has multiple biological effects, such as the promotion of cell growth and proliferation, as well as regulation of fuel metabolism. It has structural and functional similarities to insulin and plays a role in glucose homeostasis together with insulin growth factor binding protein 3 (IGFBP3), which binds the majority of circulating IGF1 (AnekeNash et al. 2017, Xie et al. 2015). IGF1 is known to promote cancer development by inhibiting apoptosis and stimulating cell proliferation. Epidemiological studies have reported a positive association between circulating IGF1 levels and various tumors, especially breast, colon, prostatic and adrenocortical cancer (ACC) (Shanmugalingam et al. 2016). IGF2 is a widely expressed mitogenic peptide primarily regulating fetal development and differentiation, but its role in adults is little understood (Kadakia and Josefson, 2016). IGF2 levels have been found to be associated with metabolic parameters such as insulin resistance or bodyweight (Murphy 2003). In adrenocortical tumors, especially ACC, IGF2 is the most frequently and strongly overexpressed gene (Kool et al. 2015).

Epidermal growth factor (EGF) is a small protein of $6 \mathrm{kDa}$ containing 53 amino acids comprising three disulfide bridges. It is characterized by mitogenic activity and so can be involved in the processes of cell growth and tumorigenesis. In fact, EGF is a protein contained in a network of growth factors and receptors that controls the growth and division of cells (Yarden 2001). EGF receptor (EGFR) has been demonstrated to have a pivotal role in tumorigenesis, with many human solid tumors overexpressing EGFR, including colon, breast, lung cancer, and ACC (Adam et al. 2010). Studies showed that EGFR is overexpressed in more than threequarters of ACC cases. Rarely, its expression was demonstrated also in ACA (Adam et al. 2010).

From the clinical point of view, components of the IGF system are at a first-place considered as diagnostic serum and/or tissue biomarkers of a given cancer, they also serve as prognostic factors and attractive target of modern anti-tumor therapies. There are only a few studies evaluating serum levels of IGFs, EGF, and VEGF and assessing their relationship to ACA (Kasprzak et al. 2017). The objective of the present study is to assess and compare metabolic parameters, IGFs (IGF-1, IGF-2, and IGFBP-3), EGF, and vascular endothelial growth factor (VEGF) in patients with NFA and control subjects. It also aims to determine the relationship between growth factors and insulin or serum cortisol in the group of patients with NFA.

\section{Patients and Methods}

Patients with AI sized $>1 \mathrm{~cm}$ in the longest dimension found on computed tomography (CT) examination performed for other reasons were selected for the present study. From each patient, we obtained the data about tumor size and side location. AIs had to have characteristics of adenoma (homogenous low density mass) on computed tomography (CT) images or adenoma was confirmed histologically after adrenalectomy in all patients. Adrenalectomy was indicated in patients with tumor size $>4 \mathrm{~cm}$ or if slight cortisol overproduction was confirmed (low ACTH and/or DHEA-S levels and serum cortisol concentration $\leq 60 \mathrm{nmol} / 1$ after a 1 -mg overnight dexamethasone suppression test). Patients with pheochromocytoma, overt Cushing syndrome, or primary hyperaldosteronism, as well as patients with acromegaly, were excluded from the study.

Control group was selected from the age-matched general population, exclusion criteria included severe heart failure, liver and/or kidney disease acromegaly and any adrenoal pathology. All control subjects had to have a negative ultrasound (US), CT, or magnetic resonance (MRI) imaging of kidneys and adrenals. The CT characteristics of adenoma included a tumor density lower than $18 \mathrm{HU}$, relative washout $>50 \%$ over 10-15 minutes and well margination.

Data on age, gender, presence of hypertension, diabetes mellitus, dyslipidemia, and metabolic syndrome were obtained for each patient.

All subjects involved in the study signed a written informed consent and the study was approved by the Ethical Committee of the University Hospital in Košice, Slovakia.

\section{Ethics approval}

The study was approved by the Ethical Committee of the University Hospital in Košice, 
Slovakia. All procedures performed in studies involving human participants were in accordance with the ethical standards of the institutional and/or national research committee and with the 1964 Helsinki declaration and its later amendments or comparable ethical standards.

\section{Laboratory tests}

Venous blood was drawn in all subjects in the morning after a 12-hour fasting period into polyethylene tubes without an anticoagulation agent (for serum) and into tubes with ethylenediaminetetraacetic acid (EDTA) anticoagulant. All samples were immediately centrifuged at $4{ }^{\circ} \mathrm{C}$ and both serum and plasma were stored at $-80{ }^{\circ} \mathrm{C}$ until they were processed.

Serum glucose levels as well as lipid profile (total cholesterol, low-density lipoproteins (LDL), highdensity lipoproteins (HDL), and triglycerides (TAG) were analyzed routinely using an autoanalyzer (Roche Diagnostics $\mathrm{GmbH}$ ). Insulin concentrations were determined from serum by immunoradiometric assay (Beckman Coulter, Inc.). The homeostatic model assessment of insulin resistance (HOMA-IR) was calculated by the equation: HOMA-IR $=$ (glucose $\times$ insulin)/22.5.

Serum cortisol and ACTH were measured from the same morning sample using RIA kit Immunotech Beckmann (Czech Republic) and RIA kit BRAHMS (France), respectively.

The levels of VEGF and EGF were determined in blood serum $(100 \mu \mathrm{l})$ by Cytokine \& Growth Factors High Sensitivity Array (Cat. No. EV3623, Randox Laboratories Ltd. Crumlin, UK) by Randox Evidence Investigator Analyzator (Serial No: EI-15354, Randox Laboratories Ltd. Crumlin, UK) simultaneously. Assay sensitivity varied from $0.12 \mathrm{pg} / 1$ to $2.12 \mathrm{pg} / 1$ (https://www.eposters.net/pdfs/multiplexedmeasurement-of-cytokines-in-saliva-with.pdf) depending on specific cytokine or growth factor marker. The repeatability of the assay for individual cytokine or growth factor marker was determined using the quality controls provided with the CTK HS kit. The levels of IGF1, IGF2, and IGFBP3 were determined using immunoradiometric assays (Beckman Coulter, Inc).

\section{Statistical analysis}

SPSS Statistics Faculty Pack (IBM, USA) was used for statistical analysis. Categorical variables were summarized as frequency counts and percentages. Continuous variables were summarized as the median and range. Comparisons of percentages in cross-tabulated tables to assess independence or association of factors used Fisher's exact test for both simple 2 x 2 contingency tables and those with more rows and/or columns. This test assumes that neither the rows nor columns have an inherent ordering, as was the case in our applications. Wilcoxon Rank Sum test was used for numeric value comparisons. Linear regression analysis was used to assess correlations between variables. Multiple logistic regression analysis was performed to determine which variables were associated with Ais. Values were considered to be statistically significant at $p \leq 0.05$. All reported p-values are two-sided.

\section{Results}

\section{Patients characteristics}

Forty-three patients (14 [32.56\%] males and 29 [67.44\%] females) with AI were included in the

Table 1. Patients' and control group characteristics and prevalence of metabolic syndrome and its components

\begin{tabular}{lccc}
\hline & Patients & Controls & p-value \\
\hline Total $(N)$ & 43 & 40 & 0.17 \\
Males $(N, \%)$ & $14(32.56 \%)$ & $19(47.5 \%)$ & 0.17 \\
Females $(N, \%)$ & $29(67.44 \%)$ & $21(52.5 \%)$ & 0.69 \\
Age (median, range) & $66.81(44.23-82.72)$ & $67.7(26.52-91.44)$ & 0.34 \\
Hypertension $(N, \%)$ & $35(81.4 \%)$ & $29(72.5 \%)$ & 0.06 \\
T2DM (N,\%) & $9(20.93 \%)$ & $18(45.0 \%)$ & 0.11 \\
Dyslipidemia (N,\%) & $13(30.23 \%)$ & $19(47.5 \%)$ & 0.87 \\
Metabolic syndrome (N,\%) & $7(16.28 \%)$ & $6(15.0 \%)$ & - \\
Tumor size (mm, median and range) & $20(9-110)$ & - & \\
\hline
\end{tabular}


present prospective case-control study. In all patients, AI had characteristic CT image of adenoma or adenoma was confirmed histologically after adrenalectomy. The median age of patients was 66.8 (range $44-83$ ) years. The age-matched control group consisted of 40 (19 [47.5\%] males, 21 [52.5\%] females) subjects with median age of 67.7 (range 26 -91) years (Table 1) and negative imaging findings on adrenal glands. There were no significant differences in the prevalence of type 2 diabetes mellitus (T2DM), metabolic syndrome, hypertension, or dyslipidemia between patients and the control group $(\mathrm{p}=0.06, \mathrm{p}=0.87, \mathrm{p}=0.34, \mathrm{p}=0.11$, respectively, Table 1).

Table 2. Biochemical characteristics of AI patients and controls

\begin{tabular}{lccc}
\hline Parameter & Patients (median, range) & Controls (median, range) & p-value \\
\hline Glucose $(\mathrm{mmol} / \mathrm{l})$ & $5.35(3.8-10.2)$ & $5.6(3.1-16)$ & 0.459 \\
Insulin $(\mathrm{mIU} / \mathrm{l})$ & $14.6(0.75-78.7)$ & $9.7(0-175)$ & 0.294 \\
Cortisol $(\mathrm{AM}, \mathrm{nmol} / \mathrm{l})$ & $389(44.5-788.6)$ & - & - \\
ACTH $(\mathrm{pmol} / \mathrm{l})$ & $3.37(0.46-11.33)$ & - & - \\
HOMA-IR & $3.94(0.16-30.43)$ & $2.5(0-38.11)$ & 0.685 \\
Total cholesterol $(\mathrm{mmol} / \mathrm{l})$ & $5.27(2.92-7.72)$ & $4.57(1.93-7.01)$ & 0.040 \\
LDL cholesterol (mmol/l) & $3.39(1.27-5.44)$ & $2.94(1.29-5.36)$ & 0.156 \\
HDL cholesterol $(\mathrm{mmol} / \mathrm{l})$ & $1.3(0.88-1.84)$ & $1.095(0.41-2.39)$ & 0.047 \\
TAG $(\mathrm{mmol} / \mathrm{l})$ & $1.4(0.72-2.73)$ & $141.24(22.8-713.02)$ & 0.503 \\
VEGF $(\mathrm{pg} / \mathrm{ml})$ & $155.71(24.45-483.93)$ & $45.075(3.7-224.03)$ & 0.529 \\
EGF $(\mathrm{pg} / \mathrm{ml})$ & $35.02(1.5-390.69)$ & $100.84(24.64-218.38)$ & 0.307 \\
$I G F 1(\mathrm{ng} / \mathrm{ml})$ & $157.17(47.33-288.41)$ & $529.2(233.61-1243.21)$ & 0.016 \\
$I G F 2(\mathrm{ng} / \mathrm{ml})$ & $666.12(338.16-1298.7)$ & $1305.56(278.09-3444.35)$ & 0.005 \\
IGFBP3 $(\mathrm{ng} / \mathrm{ml})$ & $1874.42(1009.17-3178.72)$ & 0.004 \\
\hline
\end{tabular}

EGF - epidermal growth factor, HOMA-IR - homeostatic model assessment of insulin resistance, IGF - insulin-like growth factor, IGFBP3 - IGF binding protein 3, HDL - high-density lipoproteins, LDL - low-density lipoproteins, TAG - triacylglycerols, VEGF - vascular endothelial growth factor
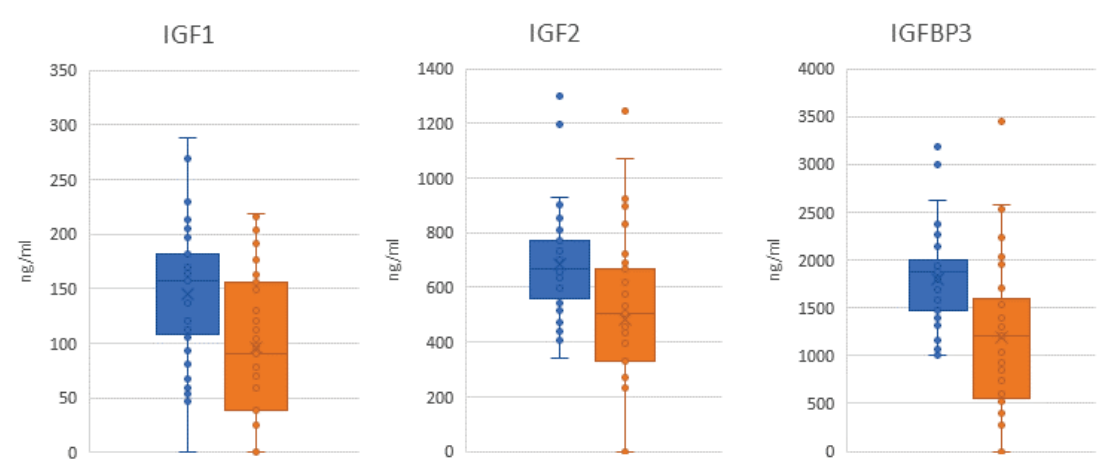

Fig. 1. Studied growth factors serum concentrations in patients and controls. EGF - epidermal growth factor, IGF insulin-like growth factor, IGFBP3 - IGF binding protein 3, VEGF - vascular endothelial growth factor
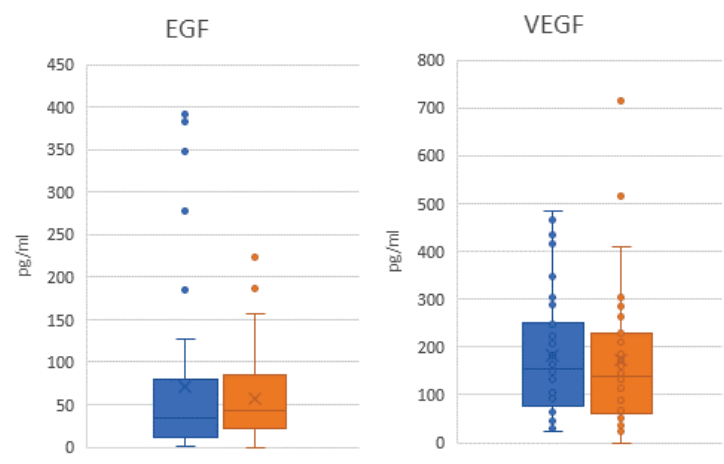

patients

controls 


\section{Biochemical results}

There were no significant differences in glycemia, insulinemia, insulin resistance index (HOMAIR), total and LDL cholesterol between AI patients and control group subjects. However, HDL levels were lower by $0.205 \mathrm{mmol} / 1$ in the control group when compared to AI patients $(1.095$ vs. $1.3 \mathrm{mmol} / \mathrm{l})$, which was on the border of statistical significance $(\mathrm{p}=0.047$, Table 2$)$.

When looking at the growth factor and interleukin levels in the AI patients and control group, no significant differences were found in the levels of VEGF and EGF ( $\mathrm{p}=0.529$ and $\mathrm{p}=0.307$, respectively, Fig. 1 . IGF1, IGF2 as well as IGFBP3 concentrations were significantly higher in the group of patients with $\mathrm{AI}$ when compared to the control group $(\mathrm{p}=0.016, \mathrm{p}=0.005$, $\mathrm{p}=0.004$, respectively, Fig. 1).

There was an indirect relationship between glycemia and EGF levels in patients with AI $(\mathrm{p}=0.026)$. No correlation was found between serum morning cortisol levels and growth factor concentrations (Table 3).

No significant correlation between adrenal tumor size and concentration of insulin $(\mathrm{p}=0.844)$, IGF1 $(\mathrm{p}=0.570)$, IGF2 $(\mathrm{p}=0.974)$, IGFBP3 $(\mathrm{p}=0.709)$, VEGF $(\mathrm{p}=0.448)$, or EGF $(\mathrm{p}=0.074)$ was found in patients with AI (Table 3).

Using logistic regression analysis, no association between AIs and growth factors (IGF1, IGF2, IGFBP3, VEGF, and EGF) was found (Table 4). In addition, no association between subclinical hypercortisolism and growth factors has been detected in this study.

Table 3. Correlations between tumor size or serum cortisol levels and metabolic variables and growth factors in patients with AI

\begin{tabular}{lcc}
\hline & $\begin{array}{c}\text { Size of tumor } \\
\text { (p-value) }\end{array}$ & $\begin{array}{c}\text { Serum } \\
\text { cortisol } \\
\text { (p-value) }\end{array}$ \\
\hline Glucose & 0.191 & 0.846 \\
Insulin & 0.844 & 0.739 \\
VEGF & 0.448 & 0.301 \\
EGF & 0.07 & 0.942 \\
IGF1 & 0.570 & 0.764 \\
IGF2 & 0.975 & 0.301 \\
IGFBP3 & 0.709 & 0.672 \\
\hline
\end{tabular}

EGF - epidermal growth factor, IGF - insulin-like growth factor, IGFBP3 - IGF binding protein 3, VEGF - vascular endothelial growth factor
Table 4. Association between AI and growth factors

\begin{tabular}{lcc}
\hline & OR (95 \% CI) & p-value \\
\hline (Intercept) & $0.182(-3.657-0.246)$ & 0.087 \\
$V E G F(\mathrm{pg} / \mathrm{ml})$ & $1.000(-0.004-0.004)$ & 0.920 \\
$E G F(\mathrm{pg} / \mathrm{ml})$ & $1.001(-0.005-0.008)$ & 0.753 \\
$I G F 1(\mathrm{ng} / \mathrm{ml})$ & $1.004(-0.008-0.016)$ & 0.517 \\
$I G F 2(\mathrm{ng} / \mathrm{ml})$ & $1.001(-0.004-0.005)$ & 0.710 \\
$I G F B P(\mathrm{ng} / \mathrm{ml})$ & $1.001(-0.001-0.002)$ & 0.559 \\
\hline
\end{tabular}

CI - confidence interval, EGF - epidermal growth factor, IGF insulin-like growth factor, IGFBP3 - IGF binding protein 3, OR Odds ratio, VEGF - vascular endothelial growth factor

\section{Discussion}

In the present study, we examined the serum concentrations of IGFs, IGFBP-3, EGF, and VEGF in patients with AIs with typical CT signs of benign adenomas and age-matched control subjects with normal radiological finding on both adrenal glands. Although patients with ACA did not differ in the prevalence of metabolic syndrome from controls, they had significantly higher serum IGF1 and IGF2 as well as IGFBP3.

It is well known that AIs are frequently accompanied by metabolic syndrome or its components and with increased cardiovascular risk (Elhassan et al. 2019, Di Dalmazi 2019). Several studies reported that non-functional AIs can be associated with high levels of adipocytokines such as leptin and resistin, which affect insulin resistance and cardiovascular risk factors (Ermetici et al. 2007, Akkus et al. 2019). However, data on the serum levels of growth factors in patients with pathological adrenal masses are poor. The IGF system appears to be important in the regulation of adrenal growth and hormone synthesis (Altieri et al. 2016). According to some studies, this system also plays a crucial role in cardiovascular risk and metabolic syndrome (Livingstone and Borai 2014, Desai and Patel 2015, Obradovic et al. 2019, Harada et al. 2019). IGF1 is an anabolic growth hormone, responsible for cell growth, differentiation, proliferation, and survival (Desai and Patel 2015). Some studies confirmed its association with early tumorigenesis in animals and human (Wlodarczyk et al. 2019, Wlodarczyk et al. 2018). This relationship has been confirmed in the breast, pancreatic, and colorectal cancers as well as adrenocortical carcinoma (ACC) (Shanmugalingam et al. 2016). Many studies demonstrated higher expression of IGF1 and IGF2 
receptors in ACC and larger adenomas, indicating a possible role of these growth factors in adrenal tumorigenesis (Altieri et al. 2019, Schmitt et al. 2006). Former study of Faical et al. (1998) found that adrenal adenomas and carcinomas had over $50 \%$ of IGF1 positive cells in $64 \%$ and $83 \%$ of the tissue samples, respectively. The size of the tumors with $50 \%$ of IGF1 positive cells compared with those with less than $50 \%$ was, on average, greater, but no statistical differences between IGF1 cell positivity and the corresponding clinical syndrome were observed (Faical et al. 1998). Unfortunately, there are poor data on the serum levels of IGFs in patients with ACA. In the recent study of Bahadir et al. (2018), serum IGF1 levels were significantly higher in patients with NFA in comparison to controls $(\mathrm{p}=0.001)$, while HOMA-IR was similar in both groups. This finding is in agreement with the results of our study and can indicate an association between adrenal masses and IGF1. This is supported by the fact that patients with acromegaly and increased serum IGF1 concentrations demonstrated a significantly higher prevalence of pathologic adrenal masses especially ACCs (JawiarczykPrzybylowska et al. 2019, Terzolo et al. 2000). It remains to be recognized whether the growth hormone stimulatory effect or effect of hyperinsulinemia and insulin resistance are the leading factors for ACAs development.

The impact of IGF2 in ACC has been evaluated in some immunohistochemical and clinical studies (Kasprzak et al. 2017, Altieri et al. 2019, GuillaudBataille et al. 2014). Although IGF2 receptor overexpression is observed in the vast majority of ACCs and some larger ACAs, being a very helpful predictor for malignancy in adrenal tumors, the results of studies determining serum IGF2 levels are conflicting. In the study of Patel et al. (2014) IGF2 levels were not elevated in the serum of patients with ACC compared to those with benign adenomas and healthy volunteers. There were no significant differences in the serum IGF2 concentrations between controls and ACA which is in discordance with our study. Unfortunately, we did not find other clinical studies determining the serum levels of IGF2 in patients with ACA. However, serum IGF2 concentrations were examined in many studies in patients with metabolic syndrome. Some of these studies found its increase in obesity and a positive correlation with BMI (Buchanan et al. 2001). On the other side, recent studies demonstrated lower levels of this peptide in patients with metabolic syndrome (Pouriamehr et al. 2019). Although the prevalence of metabolic syndrome or its components was similar in patients and controls in our study, increased levels of IGF2 suggest its possible role in the etiopathogenesis of ACAs together with IGF1.

However, the activity of the whole IGF system does not need to reflect the serum IGF1 and IGF2 concentrations, since the higher levels of IGFBP3 will presumably bind IGF in excess. Secondly, increased IGFs serum concentrations do not accurately reflect the paracrine IGF system activity in the adrenal tissue.

As IGFBPs modify IGF bioactivity, we investigated serum IGFBP3 in patients with ACA and controls. Based on recent data it has been suggested that both serum IGF1 and IGFBP3 are related to future risk of malignant neoplasms (Adachi et al. 2020). In our study serum levels of IGFBP3 were significantly higher in patients with ACA as compared with the control group. Currently, there are no clinical studies determining IGFBP3 in the serum of patients with adrenal adenomas. A former experimental study of Ilvesmäki et al. (1998) showed that IGFBP3 $m R N A$ is very low in normal adrenals. In adrenal tumors and hyperplastic adrenal tissue, IGFBP3 $m R N A$ expression was usually higher than in normal adrenal glands which might support our results. In the mentioned study, IGFBP3 $m R N A$ expression was also higher in ACAs with cortisol overproduction, whereas no relationship between IGF1, IGF2, IGFBP3, and serum ACTH or cortisol concentration was found.

In the present study, we did not demonstrate significant differences in the serum EGF and VEGF levels among patients with ACA and controls. There was neither significant correlation of these growth factors with the size of the ACA nor with the serum cortisol. Several studies have reported EGF receptor overexpression in ACCs but not in ACAs, implying that the EGF receptor could potentially be used as a marker for the differential diagnosis of these two tumor types (Adam et al. 2010, Zhang et al. 2014, Angelousi et al. 2018). In the literature, there are no data concerning the serum concentrations of EGF in patients with ACA, and the data on the role of VEGF in the pathogenesis of ACA is poor. Previous studies did not demonstrate any differences in the serum VEGF concentrations between AIs and controls, although patients with AIs had significantly higher concentrations of VEGF receptor-2 than healthy subjects (Qin et al. 2013, Foltyn et al. 2012). To the best of our knowledge, this is the first study assessing together serum IGFs, EGF, and VEGF in patients with benign adrenal tumors in comparison to controls. Based on the results presented in this study it is 
very difficult to postulate that IGF1, IGF2, or IGFBP3 may serve as biomarkers for ACAs or tumors in general and further clinical studies are required. Also, the growth factors in our study were measured by immunoradiometric assay or cytokine and growth factors high sensitivity array, which offer the most precise results.

Undoubtedly, our study has some limitations. The main constraint is a relatively small group of patients with AIs. Despite this fact, the statistical analysis and results allow postulating relevant conclusions that have not yet been published in the literature.

\section{Conclusion}

In summary, we found that patients with ACAs have significantly higher serum concentrations of IGF1,
IGF2, and IGFBP3 when compared to age and metabolically matched control subjects, indicating a possible role of the IGF axis in the pathogenesis of adrenocortical lesions. Serum IGFs and IGFBP3 did not correlate with the size of the ACAs. The present study did not show any correlation between IGFs or IGFBP3 and parameters of glucose or lipid metabolism. These results may support the hypothesis that the growth hormone axis rather than hyperinsulinemia and insulin resistance may be involved in the pathogenesis of ACAs.

\section{Conflict of Interest}

There is no conflict of interest.

\section{Acknowledgements}

This work was supported by the Ministry of Healthcare of the Slovak Republic 2019/32-UPJŠ-4.

\section{References}

ADACHI Y, NOJIMA M, MORI M, HIMORI R, KUBO T, YAMANO HO, LIN Y, WAKAI K, TAMAKOSHI A: Insulin-like growth factor-1, insulin-like growth factor binding protein-3 and the incidence of malignant neoplasms in a nested case-control study. Cancer Prev Res (Phila), 2020. https://doi.org/10.1158/19406207.CAPR-19-0375

ADAM P, HAHNER S, HARTMANN M, HEINRICH B, QUINKLER M, WILLENBERG HS, SAEGER W, SBIERA S, SCHMULL S, VOELKER HU, STROBEL P, ALLOLIO B, FASSNACHT M: Epidermal growth factor receptor in adrenocortical tumors: analysis of gene sequence, protein expression and correlation with clinical outcome. Modern Pathol 23: 1596-1604, 2010. https://doi.org/10.1038/modpathol.2010.153

AKKUS G, EVRAN M, SERT M, TETIKER T: Adipocytokines in non-functional adrenal incidentalomas and relation with insulin resistance parameters. Endocr Metab Immune Disord Drug Targets 19: 326-332, 2019. https://doi.org/10.2174/1871530318666181009112042

ALTIERI B, COLAO A, FAGGIANO A: The role of insulin-like growth factor system in the adrenocortical tumors. Minerva Endocrinol 44: 43-57, 2019. https://doi.org/10.23736/S0391-1977.18.02882-1

ALTIERI B, TIRABASSI G, DELLA CASA S, RONCHI CL, BALERCIA G, ORIO F, PONTECORVI A, COLAO A, MUSCOGIURI G: Adrenocortical tumors and insulin resistance: What is the first step? Int J Cancer 138: 2785-2794, 2016. https://doi.org/10.1002/ijc.29950

ANDERLOVÁ K, CINKAJZLOVÁ A, ŠIMJÁK P, KLOUČKOVÁ J, KRATOCHVÍLOVÁ H, LACINOVÁ Z, KAVÁLKOVÁ P, KREJČÍ H, MRÁZ M, PǍ̌ÍZEK A, HALUZÍK M, KRŠEK M: Insulin-like growth factor axis in pregnancy and gestational diabetes mellitus. Physiol Res 68: 807-816, 2019. https://doi.org/10.33549/physiolres.934093

ANEKE-NASH CS, XUE X, QI Q, BIGGS ML, CAPPOLA A, KULLER L, POLLAK M, PSATY BM, SISCOVICK D, MUKAMAL K, STRICKLER HD, KAPLAN RC: The association between IGF-I and IGFBP-3 and incident diabetes in an older population of men and women in the cardiovascular health study. J Clin Endocrinol Metab 102: 4541-4547, 2017. https://doi.org/10.1210/jc.2017-01273

ANGELOUSI A, KYRIAKOPOULOS G, NASIRI-ANSARI N, KARAGEORGOU M, KASSI E: The role of epithelial growth factors and insulin growth factors in the adrenal neoplasms. Ann Transl Med 6: 253, 2018. https://doi.org/10.21037/atm.2018.05.52

BAHADIR CT, ECEMIS GC, ATMACA H: Does IGF-1 play a role in the etiopathogenesis of non-functioning adrenocortical adenoma? J Endocr Investig 41: 1317-1323, 2018. https://doi.org/10.1007/s40618-018-0869-1 
BUCHANAN CM, PHILLIPS AR, COOPER GJ: Preptin derived from proinsulin-like growth factor II (proIGF-II) is secreted from pancreatic islet beta-cells and enhances insulin secretion. Biochem J 360: 431-439, 2001. https://doi.org/10.1042/bj3600431

DELIBASI T, KARBEK B, BOZKURT NC, CAKIR E, GUNGUNES A, UNSAL OO, ASLAN MS, CAKAL E: Circulating E-selectin levels and insulin resistance are associated with early stages of atherosclerosis in nonfunctional adrenal incidentaloma. Arch Endocrinol Metab 59: 310-317, 2015. https://doi.org/10.1590/23593997000000053

DESAI NA, PATEL SS: Increased insulin-like growth factor-1 in relation to cardiovascular function in polycystic ovary syndrome: friend or foe? Gynecol Endocrinol 31: 801-807, 2015. https://doi.org/10.3109/09513590.2015.1075497

Di DALMAZI G: Adrenal incidentaloma: picking out the high-risk patients. Exp Clin Endocrinol Diabetes 127: 178-184, 2019. https://doi.org/10.1055/a-0713-0598

DI DALMAZI G: Update on the risks of benign adrenocortical incidentalomas. Curr Opinion Endocrinol Diab Obes 24: 193-199, 2017. https://doi.org/10.1097/MED.0000000000000341

ELHASSAN YS, ALAHDAB F, PRETE A, DELIVANIS DA, KHANNA A, PROKOP L, MURAD MH, O'REILLY MW, ARLT W, BANCOS I: Natural history of adrenal incidentalomas with and without mild autonomous cortisol excess: a systematic review and meta-analysis. Ann Int Med 171: 107-116, 2019. https://doi.org/10.7326/M18-3630

ERMETICI F, MALAVAZOS AE, CORBETTA S, MORRICONE L, DALL'ASTA C, CORSI MM, AMBROSI B: Adipokine levels and cardiovascular risk in patients with adrenal incidentaloma. Metabolism 56: 686-692, 2007. https://doi.org/10.1016/j.metabol.2006.12.018

FAICAL S, MACIEL RM, NOSE-ALBERTI V, SANTOS MC, KATER CE: Immunodetection of insulin-like growth factor I (IGF-I) in normal and pathological adrenocortical tissue. Endocr Pathol 9: 63-70, 1998. https://doi.org/10.1007/BF02739953

FASSNACHT M, ARLT W, BANCOS I, DRALLE H, NEWELL-PRICE J, SAHDEV A, TABARIN A, TERZOLO M, TSAGARAKIS S, DEKKERS OM: Management of adrenal incidentalomas: European Society of Endocrinology Clinical Practice Guideline in collaboration with the European Network for the Study of Adrenal Tumors. Eur J Endocrinol 175: G1-G34, 2016. https://doi.org/10.1530/EJE-16-0467

FOLTYN W, STRZELCZYK J, MAREK B, KAJDANIUK D, SIEMIŃSKA L, ROSIEK V, KOS-KUDŁA B: The usefulness of determining the serum concentrations of vascular endothelial growth factor (VEGF) and its soluble receptor type 2 (sVEGF-2) in the differential diagnosis of adrenal incidentalomas. Endokrynol Pol 63: 22-28, 2012.

GUILLAUD-BATAILLE M, RAGAZZON B, DE REYNIES A, CHEVALIER C, FRANCILLARD I, BARREAU O, STEUNOU V, GUILLEMOT J, TISSIER F, RIZK-RABIN M, RENE-CORAIL F, AL GHUZLAN A, ASSIE G, BERTAGNA X, BAUDIN E, LE BOUC Y, BERTHERAT J, CLAUSER E: IGF2 promotes growth of adrenocortical carcinoma cells, but its overexpression does not modify phenotypic and molecular features of adrenocortical carcinoma. PloS one 9: e103744, 2014. https://doi.org/10.1371/journal.pone.0103744

HARADA K, HANAYAMA Y, OBIKA M, ITOSHIMA K, OKADA K, OTSUKA F: Clinical relevance of insulin-like growth factor-1 to cardiovascular risk markers. Aging Male 1-9, 2019. https://doi.org/10.1080/13685538.2019.1657083

ILVESMAKI V, LIU J, HEIKKILA P, KAHRI AI, VOUTILAINEN R: Expression of insulin-like growth factor binding protein 1-6 genes in adrenocortical tumors and pheochromocytomas. Horm Metab Res 30: 619-623, 1998. https://doi.org/10.1055/s-2007-978945

JAWIARCZYK-PRZYBYLOWSKA A, WOJTCZAK B, WHITWORTH J, SUTKOWSKI K, BIDLINGMAIER M, KORBONITS M, BOLANOWSKI M: Acromegaly associated with GIST, non-small cell lung carcinoma, clear cell renal carcinoma, multiple myeloma, medulla oblongata tumour, adrenal adenoma, and follicular thyroid nodules. Endokrynol Pol 70: 213-217, 2019. https://doi.org/10.5603/EP.a2019.0005

KADAKIA R, JOSEFSON J: The relationship of insulin-like growth factor 2 to fetal growth and adiposity. Horm Res Paediatr 85: 75-82, 2016. https://doi.org/10.1159/000443500 
KASPRZAK A, KWASNIEWSKI W, ADAMEK A, GOZDZICKA-JOZEFIAK A: Insulin-like growth factor (IGF) axis in cancerogenesis. Mutat Res Rev Mutat Res 772: 78-104, 2017. https://doi.org/10.1016/j.mrrev.2016.08.007

KHAN U: Nonfunctioning and subclinical cortisol secreting adrenal incidentalomas and their association with metabolic syndrome: A systematic review. Indian $\mathrm{J}$ Endocrinol Metab 23: 332-346, 2019. https://doi.org/10.4103/ijem.IJEM_52_19

KOOL MM, GALAC S, VAN DER HELM N, CORRADINI S, KOOISTRA HS, MOL JA: Insulin-like growth factorphosphatidylinositol 3 kinase signaling in canine cortisol-secreting adrenocortical tumors. J Vet Intern Med 29: 214-224, 2015. https://doi.org/10.1111/jvim. 12528

LIVINGSTONE C, BORAI A: Insulin-like growth factor-II: its role in metabolic and endocrine disease. Clin Endocrinol 80: 773-781, 2014. https://doi.org/10.1111/cen.12446

MURPHY LJ: The role of the insulin-like growth factors and their binding proteins in glucose homeostasis. Exp Diabesity Res 4: 213-224, 2003. https://doi.org/10.1155/EDR.2003.213

MUSCOGIURI G, DE MARTINO MC, NEGRI M, PIVONELLO C, SIMEOLI C, ORIO F, PIVONELLO R, COLAO A: Adrenal mass: insight into pathogenesis and a common link with insulin resistance. Endocrinology 158: 1527-1532, 2017. https://doi.org/10.1210/en.2016-1804

OBRADOVIC M, ZAFIROVIC S, SOSKIC S, STANIMIROVIC J, TRPKOVIC A, JEVREMOVIC D, ISENOVIC ER: Effects of IGF-1 on the cardiovascular system. Curr Pharm Design 25: 3715-3725, 2019. https://doi.org/10.2174/1381612825666191106091507

PAPANASTASIOU L, ALEXANDRAKI KI, ANDROULAKIS II, FOUNTOULAKIS S, KOUNADI T, MARKOU A, TSIAVOS V, SAMARA C, PAPAIOANNOU TG, PIADITIS G, KALTSAS G: Concomitant alterations of metabolic parameters, cardiovascular risk factors and altered cortisol secretion in patients with adrenal incidentalomas during prolonged follow-up. Clin Endocrinol 86: 488-498, 2017. https://doi.org/10.1111/cen.13294

PATEL D, ELLIS R, HOWARD B, BOUFRAQECH M, GARA SK, ZHANG L, QUEZADO MM, NILUBOL N, KEBEBEW E: Analysis of IGF and IGFBP as prognostic serum biomarkers for adrenocortical carcinoma. Annals Surg Oncol 21: 3541-3547, 2014. https://doi.org/10.1245/s10434-014-3768-5

POURIAMEHR S, BARMAKI H, RASTEGARY M, LOTFI F, NABI AFJADI M: Investigation of insulin-like growth factors/insulin-like growth factor binding proteins regulation in metabolic syndrome patients. BMC Res Notes 12: 653, 2019. https://doi.org/10.1186/s13104-019-4492-9

QIN HY, SUN H, WANG X, BAI R, LI Y, ZHAO J: Correlation between CT perfusion parameters and microvessel density and vascular endothelial growth factor in adrenal tumors. PLoS One. 8: e79911, 2013. https://doi.org/10.1371/journal.pone.0079911

SCHMITT A, SAREMASLANI P, SCHMID S, ROUSSON V, MONTANI M, SCHMID DM, HEITZ PU, KOMMINOTH P, PERREN A: IGFII and MIB1 immunohistochemistry is helpful for the differentiation of benign from malignant adrenocortical tumours. Histopathology 49: 298-307, 2006. https://doi.org/10.1111/j.1365-2559.2006.02505.x

SHANMUGALINGAM T, BOSCO C, RIDLEY AJ, VAN HEMELRIJCK M: Is there a role for IGF-1 in the development of second primary cancers? Cancer Med 5: 3353-3367, 2016. https://doi.org/10.1002/cam4.871

TERZOLO M, BOSSONI S, ALI A, DOGA M, REIMONDO G, MILANI G, PERETTI P, MANELLI F, ANGELI A, GIUSTINA A: Growth hormone (GH) responses to GH-releasing hormone alone or combined with arginine in patients with adrenal incidentaloma: evidence for enhanced somatostatinergic tone. J Clin Endocrinol Metab 85: 1310-1315, 2000. https://doi.org/10.1210/jcem.85.3.6531

WLODARCZYK B, BORKOWSKA A, WLODARCZYK P, MALECKA-PANAS E, GASIOROWSKA A: Serum levels of insulin-like growth factor 1 and insulin-like growth factor-binding protein 2 as a novel biomarker in the detection of pancreatic adenocarcinoma. J Clin Gastroenterol 2019. https://doi.org/10.5114/pg.2020.95091

WLODARCZYK B, GASIOROWSKA A, MALECKA-PANAS E: The role of insulin-like growth factor (IGF) axis in early diagnosis of pancreatic adenocarcinoma (PDAC). J Clin Gastroenterol 52: 569-572, 2018. https://doi.org/10.1097/MCG.0000000000001073 
XIE ZL, YE PS, ZHANG SK, ZHANG YS, SHEN XZ: Endogenous LPS alters liver GH/IGF system gene expression and plasma lipoprotein lipase in goats. Physiol Res 64: 721-729, 2015. https://doi.org/10.33549/physiolres.932854

YARDEN Y: The EGFR family and its ligands in human cancer. Signalling mechanisms and therapeutic opportunities. Eur J Cancer 37: S3-S8, 2001. https://doi.org/10.1016/S0959-8049(01)00230-1

ZHANG J, WANG C, GAO J, SUN J, ZENG X, WU S, LIANG Z: Adrenal cortical neoplasms: a study of clinicopathological features related to epidermal growth factor receptor gene status. Diagn Pathol 9: 19, 2014. https://doi.org/10.1186/1746-1596-9-19 